Patients of group I were given sequential H.M.G.-H.C.G. therapy, those of group II received either gonadotropins (34 cases) or clomiphene (55 cases), and those of group III were treated with clomiphene only.

Gonadotropic therapy gave better results in patients of group I than in those of group II $(65 \%$ and $44.1 \%$ of pregnancies respectively). In group II patients gonadotropins and clomiphene gave similar results $(49 \%$ and $44.1 \%$ pregnancies respectively). The results in group III were poor $(15.2 \%$ of pregnancies).

When patients are carefully selected for suitable therapy, sequential H.M.G.-H.C.G. or clomiphene therapy provides an overall pregnancy rate of approximately $57 \%$.

\section{REFERENCES}

Beck, P., Grayzel, E. F., Young, I. S., and Kupperman, H. S. (1966). Obstet. and Gynec., 27, 54.

Bishop, P. M. F. (1965). Proc. roy. Soc. Med., 58, 905.

Crooke, A. C., Butt, W. R., Palmer, R. F., Morris, R., Edwards, R. L., and Anson, C. J. (1963) 7. Obstet. Gynaec. Brit. Cwlth, 70, 604.
Dickey, R. P., Vorys, N., Stevens, V. C., Besch, P. K., Hamwi, G. J., and Ullery, J. C. (1965). Fert. Steril., 16, 485.

Diczfalusy, E., Johannisson, E., Tillinger, K. G., and Bettendorf, G. (1964). Acta endocr. (Kbh.), Suppl. No. 90, p. 35.

Gemzell, C. (1966). Fert. Steril., 17, 149.

Greenblatt, R. B., editor (1966) Ovulation. Philadelphia.

- et al. (1966). Fert Steril., 17, 742.

Igarashi, M., et al. (1967). Amer. F. Obstet. Gynec., 97, 120.

Johnson, J. E., Bunde, C. A., and Hoekenga, M. T. (1965). Presented at the 13th Annual Meeting of the Pacific Coast Fertility Society. Las Vegas, 29 October.

Kistner, R. W. (1965). Amer. F. Obstet. Gynec., 92, 380.

- (1966). Fert. Steril., 17, 569.

Lunenfeld, B., and Donini', P (1966). In Ovulation, edited by R. B. Greenblatt, p. 105. Philadelphia.

Mozes, M., et al. (1965). Lancet, 2, 1213.

Naville, A. H., Kistner, R. W., Wheatley, R. E., and Rock, J. (1964). Fert. Steril., 15, 290

Pildes, R. B. (1965). F. Amer. med. Ass., 192, No. 2, p. 217. (Abstract.)

Rabau, E., David, A., Serr, D. M., Mashiach, S., and Lunenfeld, B. (1967). Amer. 'f. Obstet. Gynec., 98, 92.

Shearman, R. P. (1966). Aust. Arch. Med., 15, 266.

Serr, D. M., Salomy, M., Rabau, E., Lunenfeld, B., and Skalka, Y. (1966). Harefuah, 71, 278.

\title{
Three Swedish Families with Porphyria Variegata*
}

\author{
B. HAMNSTRÖM, M.D. ; B. HAEGER-ARONSEN, M.D. ; J. WALDENSTRÖM, M.D., F.R.C.P. ; B. HYSING, M.D. \\ J. MOLANDER, M.D.
}

Brit. med. F., 1967, 4, 449-453

The interest in porphyrins and porphyria diseases has increased considerably during the last decades. This fact is probably partly due to the great progress made in porphyrin chemistry during that time.

In Sweden porphyria acuta intermittens (PAI) is predominant among the diseases with disturbances in the porphyrin metabolism. One of us (Waldenström) has studied this disease and its spread in our country during the last 35 years. About 600 cases are now known, half of them still living. Careful genetic studies have revealed a non-sex-linked inheritance of Mendelian dominant type. Clinically the classical symptoms are, first, severe abdominal pain which may lead to operations with fatal outcome; psychiatric symptoms, varying from short periods of confusion to severe psychosis, where sedating drugs aggravate the state; and neurological manifestations such as coma or epileptic fits, and above all pareses, including respiratory paralysis, which has often been the cause of death. We do not know of any clear-cut PAI patient with lightsensitivity. Chemically the typical findings in PAI are increased urinary excretion of porphyrin precursors-that is, porphobilinogen (PBG) and $\delta$-aminolaevulic acid (ALA). The disease has therefore been designated as pyrrholia or pyrrholoporphyria. The latent cases were found by analysis of PBG in the urine (Waldenström, 1937). The faecal excretion of porphyrins is only slightly increased or not at all increased (HaegerAronsen, 1962). The absence of preformed porphyrins inside the body has been regarded as the explanation of the lack of light-sensitivity.

- From the Departments of Medicine in Karlstad, Malmö, and Ängelholm, Sweden.
Among the white population in South Africa a great number of patients have been shown to have a special type of porphyria (Dean, 1953 ; Dean and Barnes, 1955, 1958 ; Eales, 1956, 1960). Clinically, all the symptoms typical of PAI may be present, often with light-sensitivity. In many cases only the skin is affected. As in PAI, the inheritance is dominant, non-sexlinked. Because of the varying symptoms the disease was given the name porphyria variegata (PV) by Dean and Barnes (1959). The best way to find the latent cases of this disease is to analyse the faecal excretion of porphyrins, which is almost always markedly increased. It has been claimed that only during the acute stage is the PBG and ALA excretion in the urine pathologically increased. At first the difference between PAI and PV regarding cutaneous symptoms was supposed to be due to the higher intensity of sunlight in Africa. However, the different biochemical characteristics mentioned above and the appearance of PAI in South Africa with signs and symptoms quite typical and without genetical connexion with PV (Dean, 1963) supported the earlier opinion of Waldenström that PAI and PV were two different gene defects. Dean and Barnes (1959) confirmed this statement once and for all.

Earlier, 13 Swedish cases from four different families with porphyria variegata or protocoproporphyria were reported (Waldenström and Haeger-Aronsen, 1963). We suspected that these cases, of which five were latent, represented PV, since one from each family suffered from light-sensitivity and several cases had considerably higher faecal excretion of porphyrins than is usually seen in PAI. The only case which fulfilled all the criteria so completely that the diagnosis PV could be made with certainty was that of a Danish woman (Case 3). 


\section{Material and Results}

Our material consists of 24 cases occurring in three families (Figs. 1-3). Two of the families (A and B) were descended from Smalland, in the southern part of Sweden. Genetical studies tracing the ancestors back to the middle of the nineteenth century failed to reveal any blood relationship between these two families or with any families having acute porphyria intermittens. The third family (C) is of particular interest because of its origin from the Skelleftea area, on the Gulf of Bothnia, where most PAI patients live. Some of the ancestors have been traced back to the end of the eighteenth century, but no relationship to the PAI families has been found. The so-called church books have, however, been partly destroyed by fire, and so the genetical studies have not been completed.

\section{Case Reports}

Family A. Case III : 3.

House painter, born in 1937. During 1952 to 1955 he indulged heavily in alcohol, but since then has always been sober. He married in 1958. From that time he began to feel more nervous than previously, probably partly because of domestic problems. In 1960 he took eight tablets of Diminal (butenemal + allypropymal), possibly with suicidal intention. He had to stay in hospital for one day, and was then discharged in good shape. In 1960-3 he consulted several doctors because of his nervousness and was prescribed sedatives in the form of meprobamate, with barbiturates and especially Mebumal (pentobarbitone B.P.), of which he took 0.10 $0.15 \mathrm{~g}$. almost every evening during long periods. In September 1961 he had acute pains in his arms and particularly in the thumbs. The pain was deeply located, totally independent of effort, and of a

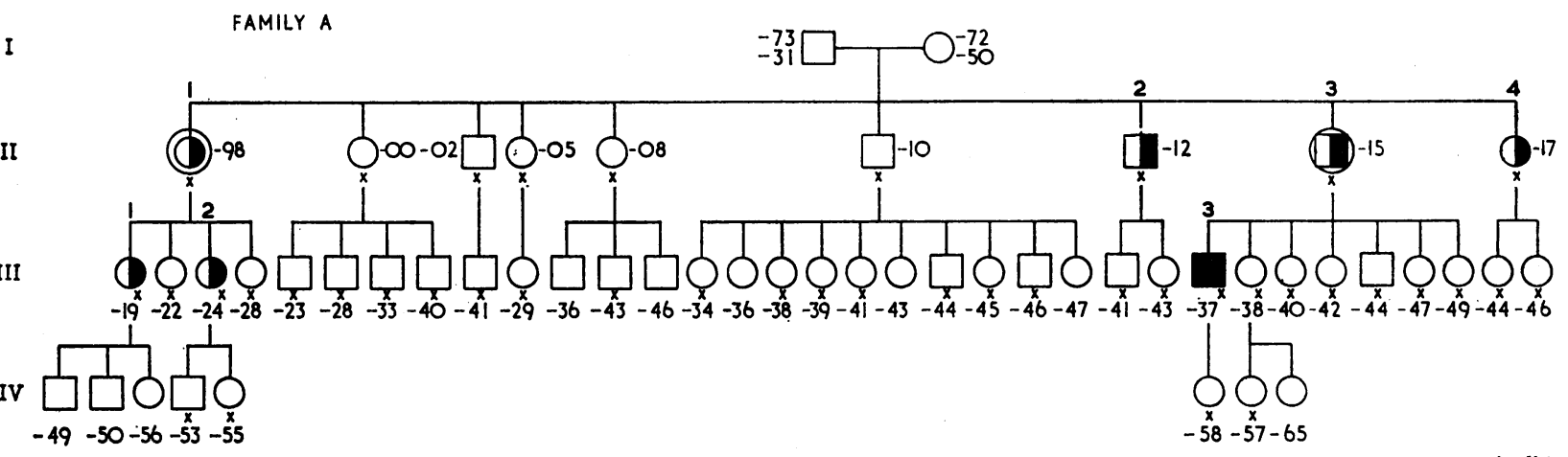

FiG. 1.-Family A, with porphyria variegata. Squares represent males and circles females; solid symbols, manifest cases; semisolid

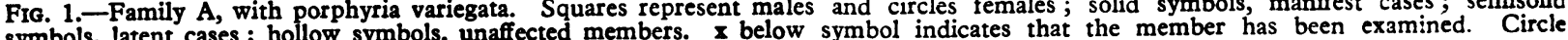
symbols, latent cases; hollow symbols, unaffected members. I below symbol indicates that the
around symbol means carrier of the porphyria trait.

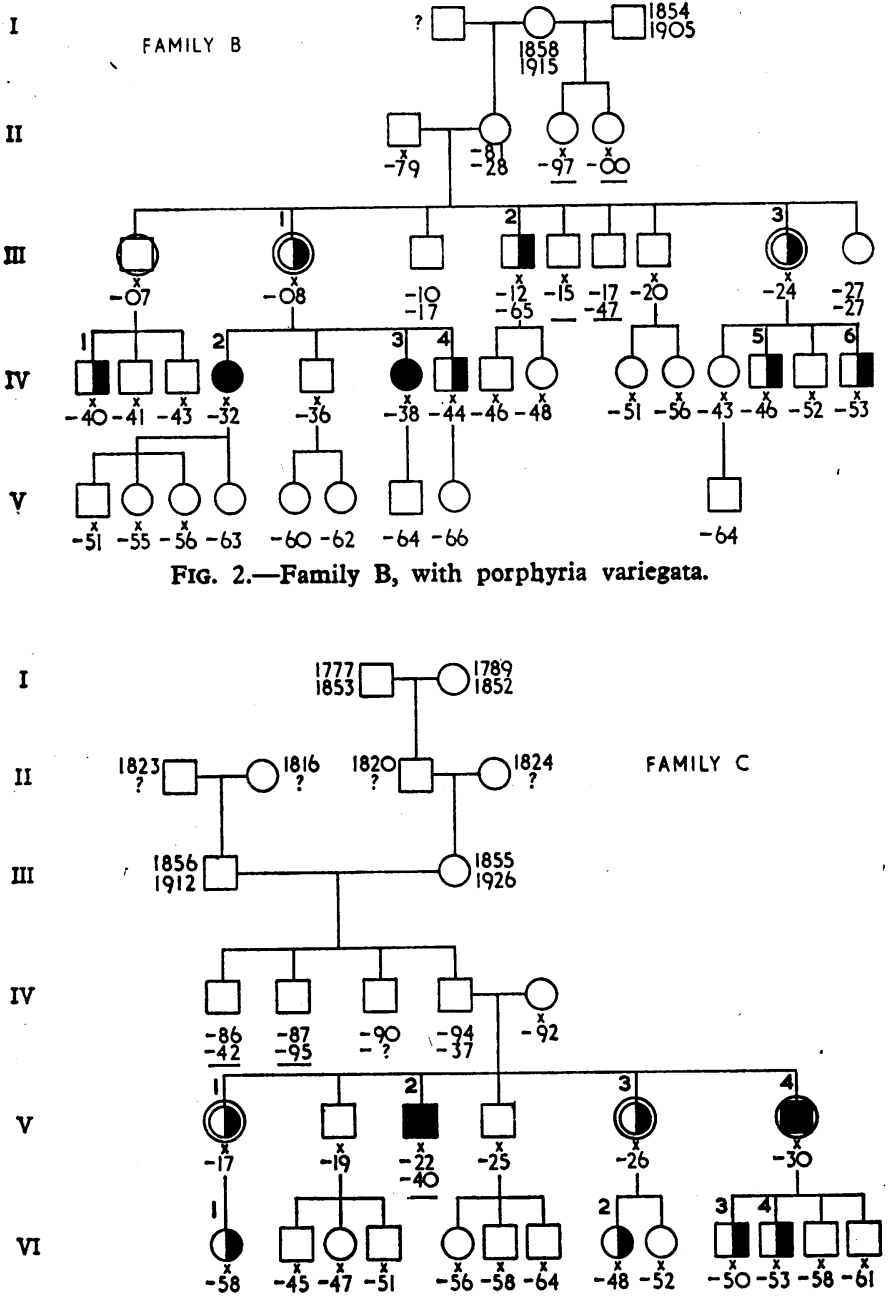

Fig. 3.-Family $C$, with porphyria variegata. continuous, very unpleasant character. The muscles were not tender. The pains disappeared spontaneously but sometimes returned later. In the summer of 1962 the patient noticed sensitivity to light for the first time. Because of his profession his hands had often to be in the sunshine during the summer, and blisters developed on the backs of them. The blisters ulcerated, and not until the autumn did they heal, with scars and pigmentation (Fig. 4). The skin was also rather sensitive to mechanical trauma. In the summer of 1963 the skin symptoms returned and were located in his face.

For many years the patient had had epigastric discomfort resembling acid gastritis (some of his brothers and sisters had the same symptoms without being carriers of the PV gene). In the autumn of 1962, when there was a sharp marital conflict, he had particu-

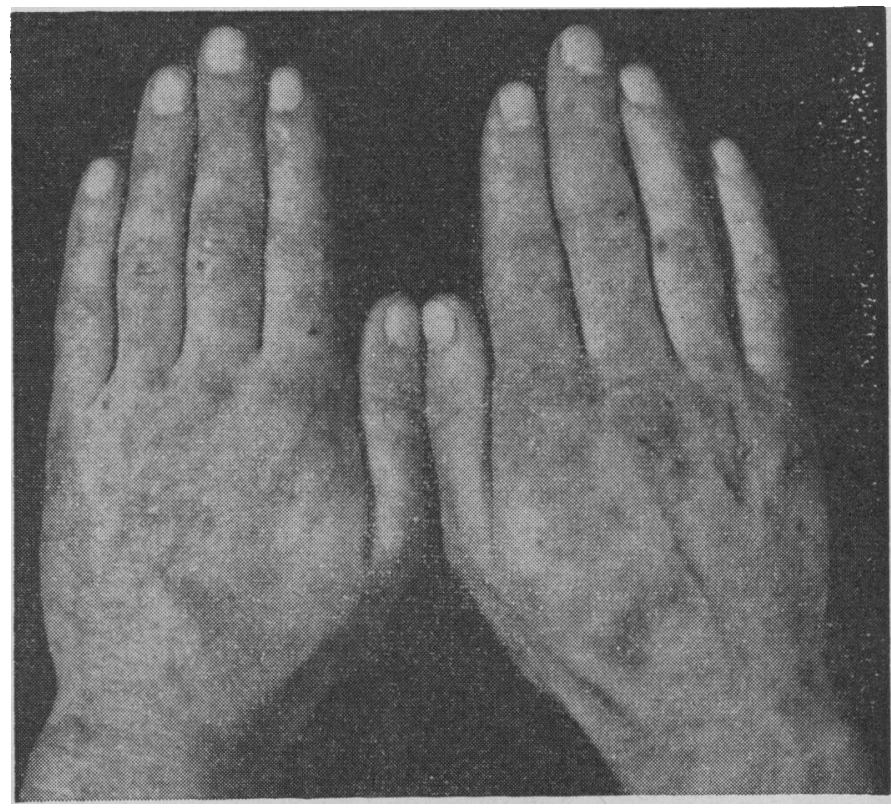

Fig. 4.-Hands of Case A, III : 3 . 
larly severe abdominal pains, which led to increased drug consumption. He at last called in a doctor, and went to the hospital surgical ward with the diagnosis of ulcus penetrans (?). He could not distinguish between the gastralgia and these new pains-no doubt explained by his porphyria-in any other way than that the latter were more severe and much more continuous. At the hospital, where he was admitted on 3 December 1962, the pains disappeared after a few days; and a confusion state with hallucinations developed. Later the patient remembered that he thought the hospital was on fire, which he could see and smell. The psychotic symptoms were so severe and he was so agitated that on 10 December he was sent to a mental hospital; there he soon improved.

During the first few days in the hospital he was given barbiturates, but from 8 December only chlorpromazine was prescribed.

The colour of his urine was always normal. The diagnosis porphyria variegata (see Table) was suspected by one of us (Hamnström) and fully confirmed by the laboratory data.

Urinary Excretion of $\delta$-aminolaevulic Acid ( $A L A$ ), Porphobilinogen $(P B G)$, Uroporphyrin (UP), and Coproporphyrin (CP) and of Faecal $C P$ and Protoporphyrin (PP) in 24 Patients from 3 Families with Porphyria Variegata

\begin{tabular}{|c|c|c|c|c|c|c|c|c|}
\hline \multirow[b]{2}{*}{ Pamily } & \multirow{2}{*}{\multicolumn{2}{|c|}{ Case }} & \multicolumn{4}{|c|}{ Urine } & \multicolumn{2}{|c|}{ Faeces } \\
\hline & & & $\begin{array}{c}\text { ALA } \\
\text { (mg.l } \\
100 \mathrm{ml} .)\end{array}$ & $\begin{array}{c}\text { PBG } \\
\text { (mg.l } \\
100 \mathrm{ml} .)\end{array}$ & 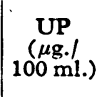 & $\begin{array}{c}\text { CP } \\
(\mu \mathrm{g} . / \\
100 \mathrm{ml} .)\end{array}$ & 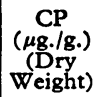 & $\mid \begin{array}{c}\text { PP } \\
\text { ( } \mu \text { g./g.) } \\
\text { (Dry } \\
\text { Weight) }\end{array}$ \\
\hline A & $\begin{array}{r}\text { II }: 1 \\
\text { II } \\
\text { II } \\
\text { II } \\
\text { II } \\
\text { III } \\
\text { III } \\
\text { III } \\
\text { III } \\
\text { II }\end{array}$ & $\begin{array}{l}L^{*} \\
\mathrm{~L} \\
\mathrm{~L} \\
\mathrm{~L} \\
\mathrm{~L} \\
\mathrm{~L} \\
\mathrm{M} t\end{array}$ & $\begin{array}{l}0.19 \\
0.27 \\
2.49 \\
0.93 \\
0.25 \\
0.35 \\
2.66\end{array}$ & $\begin{array}{l}0.09 \\
0 \cdot 10 \\
0.59 \\
0.35 \\
0 \cdot 23 \\
0 \cdot 19 \\
3 \cdot 21\end{array}$ & $\begin{array}{r}3 \\
3 \\
75 \\
16 \\
31 \\
1 \\
438\end{array}$ & $\begin{array}{r}40 \\
4 \\
91 \\
4 \\
19 \\
4 \\
281\end{array}$ & $\begin{array}{r}42 \\
14 \\
100 \\
17 \\
44 \\
149 \\
176\end{array}$ & $\begin{array}{r}53 \\
56 \\
310 \\
50 \\
105 \\
333 \\
393\end{array}$ \\
\hline B & $\begin{array}{l}\text { III }: 1 \\
\text { III }: 2 \\
\text { III }: 3 \\
\text { IV } \vdots 1 \\
\text { IV }: 2 \\
\text { IV } \vdots 3 \\
\text { IV }: 4 \\
\text { IV }: 5 \\
\text { IV }: 6\end{array}$ & $\begin{array}{l}L \\
L \\
L \\
L \\
M \\
M \\
L \\
L \\
L\end{array}$ & $\begin{array}{l}0.46 \\
0.22 \\
0.39 \\
0.94 \\
3.44 \\
0.34 \\
0.27 \\
0.48\end{array}$ & $\begin{array}{l}0.16 \\
0.82 \\
0.18 \\
0.09 \\
0.82 \\
3.61 \\
0.03 \\
0.19 \\
0.16\end{array}$ & $\begin{array}{r}13 \\
3 \\
0 \\
72 \\
130 \\
6 \\
1 \\
5\end{array}$ & $\begin{array}{r}6 \\
7 \\
3 \\
128 \\
1,022 \\
2 \\
0 \\
0\end{array}$ & $\begin{array}{r}42 \\
7 \\
134 \\
176 \\
213 \\
32 \\
42 \\
17\end{array}$ & $\begin{array}{r}110 \\
66 \\
261 \\
342 \\
626 \\
60 \\
63 \\
48\end{array}$ \\
\hline C & 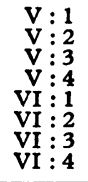 & $\begin{array}{l}\mathrm{L} \\
M \\
\mathrm{~L} \\
\mathrm{M} \\
\mathrm{L} \\
\mathrm{L} \\
\mathrm{L} \\
\mathrm{L}\end{array}$ & $\begin{array}{l}0.17 \\
0.15 \\
0.68 \\
0.47 \\
2.00 \\
0.04 \\
0.19\end{array}$ & $\begin{array}{l}0.08 \\
0.03 \\
0.09 \\
0.13 \\
0.08 \\
0.06 \\
0.06\end{array}$ & $\begin{array}{c}20 \\
++ \\
8 \\
14 \\
7 \\
0 \\
5 \\
27\end{array}$ & $\begin{array}{r}3 \\
20 \\
3 \\
3 \\
1 \\
2 \\
46\end{array}$ & $\begin{array}{r}86 \\
401 \\
2,381 \\
85 \\
11 \\
307 \\
151\end{array}$ & $\begin{array}{r}34 \\
106 \\
378 \\
16 \\
51 \\
89 \\
77\end{array}$ \\
\hline \multicolumn{3}{|c|}{$\begin{array}{l}\text { Normal upper limits } \\
(\mathrm{m}+2 \text { S.D. })\end{array}$} & 0.60 & 0.20 & 11 & 15 & 6 & 39 \\
\hline
\end{tabular}

The patient left the hospital in a good condition. During the late spring of 1963 he began to work outdoors again, but his skin condition was aggravated, and he had very severe abdominal pains. $\mathrm{He}$ knew the risks of barbiturates, and has denied having taken such medicine after 1962 . Since that time he could not take alcohol either, because it caused abdominal pains.

In July 1963 he again developed confusion. He was sent to hospital, where he spent nine days without receiving any barbiturates and was discharged in a good condition. Since then he has not had any abdominal or psychiatric crises, nor has he shown any neurological symptoms. His physical status was always mainly normal. His blood pressure, for example, was almost normal, and he had had no tachycardia, not even in the acute stage of the disease. Routine blood analyses showed nothing abnormal. In the acute stage, however, an increased activity of serum alanine aminotransferase and serum aspartate aminotransferase to a maximum of 204 units and 142 units respectively was registered. Later the transaminases became normal.

Analysis of urine and faeces from 41 of the proband's relatives was performed. It was then found that the patient's father (Case II :3), two of the father's sisters (Cases II : 1 and II :4), one of the father's brothers (Case II:2), and two cousins (Cases III: 1 and III :2) were also carriers of the porphyria variegata trait (see Table). As they had never had any symptoms typical of porphyria variegata they were considered to be latent cases. The grandmother who died in 1950 was said to have had a vesicular dermatitis occasionally on the back of her hands. Maybe she also was a carrier of the gene.
Family B. Case IV : 2.

Housewife, born in 1932. Up to 1960 she had always been in good health. She had had three pregnancies during 1951-6 without any complications. Since 1960 she had been nervous and irritable periodically. In November 1962 she started to use barbiturates during these occasions. In early December of the same year she was taken ill wich abdominal pains, restlessness, and insomnia. She increased her barbiturate consumption but became rapidly worse, with pains and numbness in her extremities. She also felt sick and began to vomit. On 20 December she was admitted to the obstetrical and gynaecological department of Ängelholm. There she was found to be in the sixth week of gestation, and was dehydrated and mentally confused. After some days' treatment with chlorpromazine, water, and electrolytes she rapidly improved, but was mentally exalted and unstable during her stay at the hospital. At her own request she left the hospital on 24 December, and while at home continued to take barbiturates. Because of illhealth she was readmitted after 24 hours at home. It was noticed that her urine was dark brown. As acute porphyria intermittens was suspected, a PBG analysis was made on her urine. Since the excretion of this metabolite was markudly increased the suspected diagnosis was regarded as confirmed.

On admission she was mentally lucid, but she complained of double vision and severe pains in her extremities and abdomen. Her reactions bore witness to her agony and she could not lie still. Neurological examination revealed normal conditions. The electrocardiogram showed sinus tachycardia but was otherwise normal. Her blood pressure was 160/100 mm. Hg. Routine blood analyses were mainly normal with the exception of a moderate hypochromia (Hb 11.2 g./100 ml., R.B.C. 4.1 mill./cu. mm.) and a slightly increased serum alanine aminotransferase (56 units). For analyses of porphyrins and their precursors in urine and faeces see Table.

She was treated with adrenocorticotrophic hormone, chlorpromazine, and morphine. During this treatment she rapidly felt better. On 9 January 1963 she had fully recovered and left the hospital. It was then discussed whether she would be allowed to continue her pregnancy, but as the patient herself was very eager to do so and she had had three pregnancies without any complications, she was allowed to continue it.

She was well until the 32nd week (July 1963), when she had to be taken to hospital because of intense itching. She had scratches all over her body and symptoms which, according to the consultant dermatologist, seemed to be a dermatitis artefacta. She had no icterus. The scratches as well as the itching disappeared rapidly on symptomatic therapy. The analyses of ALA and PBG are given in the Table.

On 12 August 1963 the patient gave birth, without any complications, to a well-shaped girl, weighing $4,350 \mathrm{~g}$. Since then she has felt well with the exception of some short periods with slight colicky pains.

On analysing the urine and faeces of 26 of the proband's relatives for porphyrins and their precursors, we found another eight cases with pathological excretion of porphobilinogen (see Table and Fig. 2). These cases were: the sister (Case IV:3), the mother (Case III:1), one uncle (Case III:2), one aunt (Case III:3), one brother (Case IV:4), and three cousins (Cases IV:1, IV:5, and IV:6). The latter seven were clinically free of symptoms and consequently were regarded as latent cases, while the sister had had some troubles of colicky type, until then unaccountable, and she was therefore regarded as a manifest case of acute intermittent porphyria. Case IV: 1 is especially interesting, as his father, who must be a carrier of the PV trait, seems to have a normal porphyrin metabolism with a normal urinary and faecal excretion of porphyrins. This we have never found in carriers of the PAI trait (Waldenström and Haeger-Aronsen, 1964).

\section{Family B. Case IV : 3 .}

This patient, born in 1938, was an unmarried practical nurse in a nursing-home. During childhood she had frequent bouts of unexplained colicky pain in the left side of her abdomen. She had no recollection of dark urine during these bouts. In November 1964 she was admitted to the gynaecological clinic because of pains in the lower abdomen. Abrasio mucosae uteri was performed. Three days later she experienced severe abdominal pains. A left-sided gonorrhoeic salpingıtis was diagnosed and treatment with antibiotics was started. 
In January 1963 the patient's ALA and PBG excretion had been checked when her sister's (Case IV:2) porphyria was discovered. The excretion was at that time abnormally high, and when rechecked during the current hospitalization the excretions were again found to be very high (see Table). The patient was therefore admitted :o Malmö General Hospital. On admission she was nauseated and complaining of pains in her abdomen, the heart rate was 90-100 beats/min., and she vomited frequently. Because of her sister's diagnosis she was thought to suffer from the same condition. When, however, one of us (Waldenström) examined the patient the day after admission several blisters and scars on the back of the hands, the forehead, and the nose were discovered. It was then suspected that she suffered from PV rather than PAI. This was confirmed when the excretion of porphyrins in the stools was found to be raised to a level never seen in PAI (Haeger-Aronsen, 1962).

During the past few years the patient has had shorter periods of colicky pains and, especially during the summers, there have been several blisters on her hands. Her family think that she has become a little more nervous.

An appointment was made with the sister (Case IV:2), whom we had not seen earlier at Malmö. On physical examination she too was found to have blisters and scars on her hands and nose. She reported spontaneously that her skin had become more brittle during recent years, and she also was subsequently found to have high amounts of porphyrins in her stools.

\section{Family C. Case V : 2.}

This man, an unmarried machinist born in 1922, had been healthy up to the age of 18 , when he was admitted to hospital because of aching pains in the lower quadrants of the abdomen, nausea, and vomiting. On admission the abdomen was soft and the urine was porter-coloured. Analysis of the urine by one of us (Waldenström) revealed large amounts of uroporphyrin. The diagnosis of acute intermittent porphyria was established-porphyria variegata being unknown at the time.

The patient's condition deteriorated rapidly, and he died in an aspiration pneumonia a few days after the diagnosis was established. At necropsy nothing remarkable was found.

\section{Family C. Case V : 4.}

A driving instructor, born in 1930, had good health up to 1962 , when he experienced aching pains in the abdomen. As one brother (Case V:2) had died with porphyria he consulted a physician, who, however, did not discover anything remarkable. Routine laboratory tests and PBG in urine were all within normal limits. $\mathrm{He}$ was admitted to hospital for four days in October 1963 because of tonsillitis, and treated with penicillin. Dark urine was noted, but no analysis of porphyrins or their precursors was made. The patient had no gastrointestinal symptoms. In August 1966 he was seen by one of us (Haeger-Aronsen) because of backache and intermittent colicky cramps. Several partly pigmented pinhead-sized scars were noted on the back of the hands, particularly in the metacarpophalangeal areas (Fig. 5). The patient reported that during recent years the skin of his hands had become more frail and that he developed chaps and blisters after the slightest trauma. The presence of PV was suspected, and was confirmed by stool analysis, which revealed high excretion of porphyrins (see Table). The patient has never had any symptoms from the central nervous system.

Urine and stool analyses on mother, siblings, and their offspring have shown the mother to be negative, while two sisters (Cases V:1 and $\mathrm{V}: 3$ ), two sons (Cases VI:3 and VI:4), and two nieces (Cases VI: 1 and VI:2) are latent. The patient's father died at the age of 42 from pulmonary tuberculosis. His hospital records (Piteå) stated that on three separate occasions his urine was darkish yellow. Porphyrin analysis was not performed.

\section{Discussion}

The discovery that the diagnosis porphyria variegata was the correct one in families where the existence of porphyria acuta intermittens earlier had been believed to be confirmed (families B and C) emphasizes the importance of adding faecal analyses for porphyrins to the examination of urine for the presence of porphyrins and their precursors. Not until the level of faecal porphyrins has been established will it be possible to differentiate between porphyria acuta intermittens and porphyria variegata in the absence of skin symptoms.

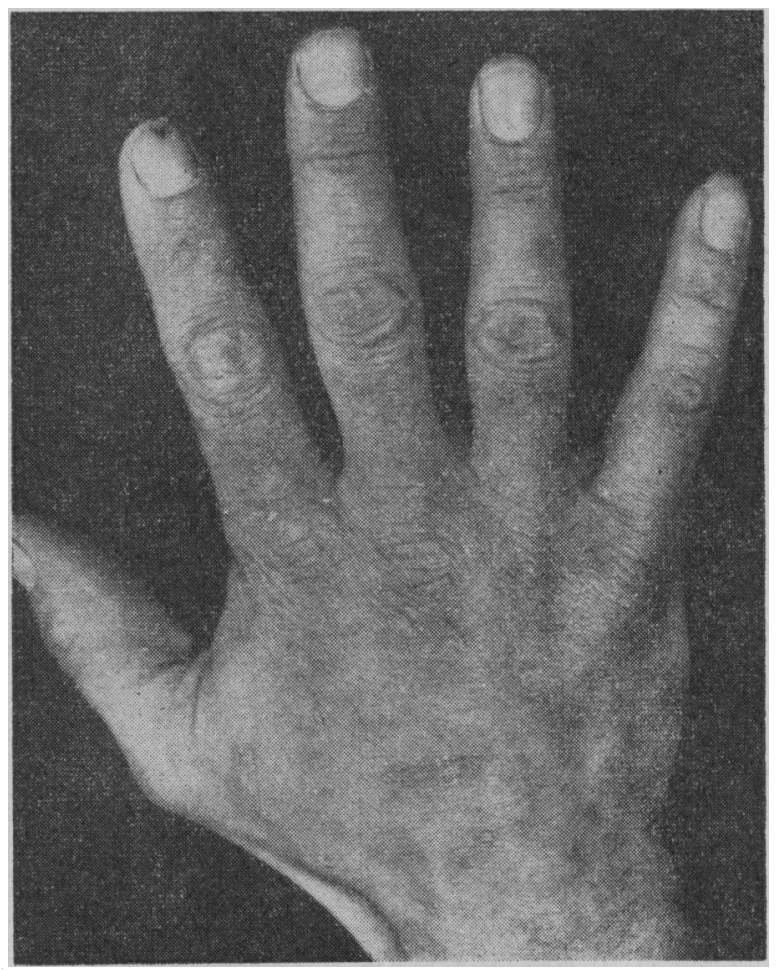

FIG. 5.-Hand of Case C, $V: 4$.

From a nosological point of view and also genetically it is of great interest to find out if the two porphyrias with acute abdominal symptoms, one with and one without cutaneous manifestations, are in any way related or are quite independent. We have previously tried in Sweden to discover if cutaneous porphyria might be present in any members of our (approximately) 125 thoroughly studied families with acute intermittent porphyria. So far we have not observed any such cases. It has also become clear that the limited number of cases with the various cutaneous porphyria types have no predilection for the north of Sweden, whereas this is the part of the country

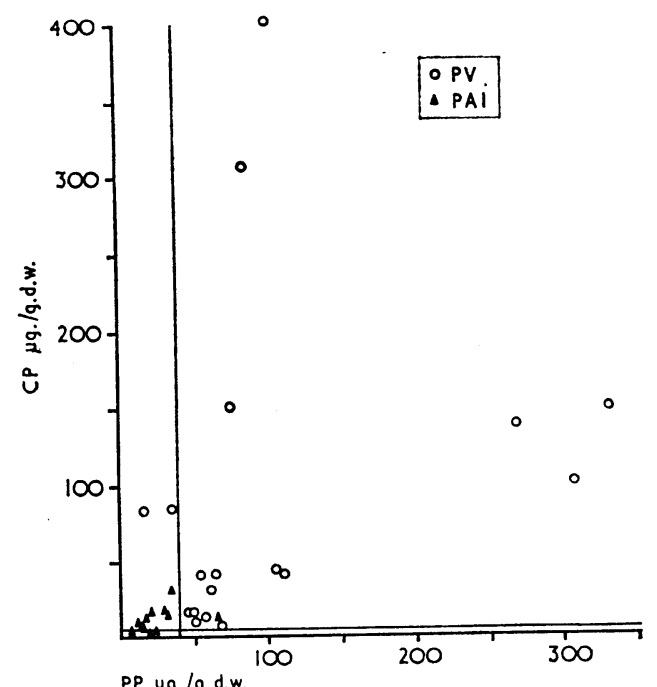

Fig. 6.-Faecal excretion of $C P$ and $P P$ in 18 patients with latent porphyria variegata (PV) and in 12 patients with latent porphyria acuta intermittens (PAI). Inserted vertical and horizontal lines indicate upper limit of normal range of excretion of PP and $C P$ respectively. 
where acute intermittent porphyria is very common. A third approach to this problem would be if we could state that the increase in faecal porphyrins characteristic of South African porphyria could be found in members of families with what is believed to be acute intermittent (Swedish) porphyria. So far this has not been possible. Another problem that we have been trying to solve is the following. Could it be that the large number of persons with latent porphyria in Sweden belonging both to PAI and to PV families have about the same biochemical picture, or is there a sharp demarcation line between these groups? We have therefore plotted the data for faecal porphyrins from 18 latent members of our three variegata families in Sweden, together with the data from some persons with latent PAI. This has also been done with urinary ALA and PBG values (Figs. 6 and 7). The graphs clearly show that

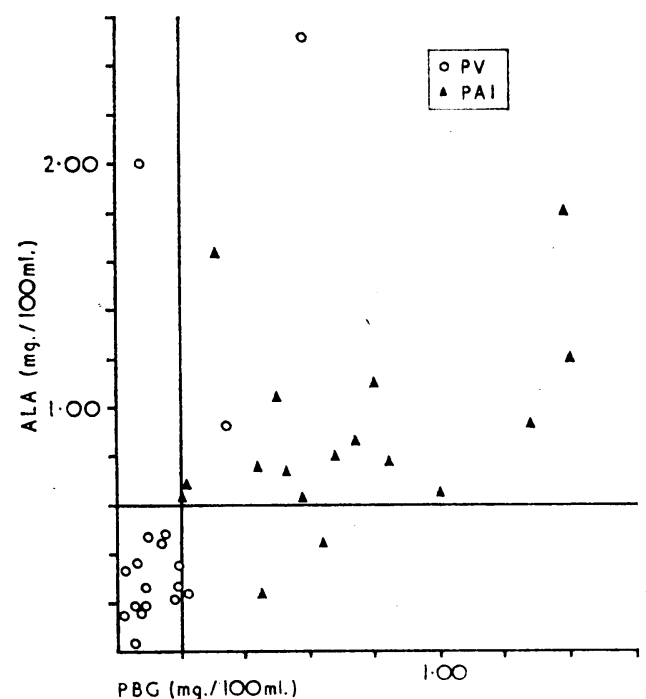

Fig. 7.-Urinary excretion of ALA and PBG in 18 patients with latent $P V$ and in 17 patients with latent PAI. Inserted vertical and horizontal lines indicate upper limit of normal range of excretion of $\mathrm{PBG}$ and ALA respectively. the two diseases have different excretory patterns: PV with relatively high faecal porphyrins but mostly normal urinary ALA and PBG, PAI with near normal faecal porphyrins but high ALA and PBG in the urine.

Two different interpretations of the findings regarding these disease pictures have been given. One interpretation, represented among others by Dean, Barnes, and the Malmö group, is that they are fundamentally different. The other, with Watson (1960) as the chief advocate, is that they are "mixed" and that some members for some reason or other also develop skin sensitivity. The most elegant way to prove that the diseases are different would be if they could be shown to be linked and not linked to some well-defined heritable condition. Such studies on our very extensive material are now in progress.

\section{Summary}

The three first families with porphyria variegata from Sweden are described. Two of them are descended from Småland, in southern Sweden. In spite of tracing the families back to the beginning and middle of the nineteenth century no relationship has been found with any family in which acute porphyria intermittens has occurred. In all, 24 cases of porphyria variegata are reported -5 manifest and 19 latent.

Supported by a grant to J. Waldenström and B. Haeger-Aronsen from the Swedish Medical Research Council.

\section{REFERENCES}

Dean, G. (1953). Brit. med. F., 2, 1291.

(1963). The Porphyrias. London.

(1963). The Porphyrias. Londion. med. 7., 2, 89.

and Barnes, H. D. (1955). (1958). Ibid., 1, 298. . Afr. med. 33, 246.

Eales, (1959). S. Afr. med.

Eales, L. (1956). Ibid., 30, 924. . Med., 6, 63

Haeger-Aronsen, B. (1962). Scand. \%. clin. Lab. Invest., 14, 397.

Hamnström, B. Haeger-Aronsen, B., and Waldenström, J. (1964). Lecture in Svenska föreningen för invärtes medicin: Porphyria variegata i Sverige.

Whaldenstrom, J. (1937). Acta med. scand., Suppl. No. 82.

Waldenstrom, J. (1937). Acta med. scand., Suppl. No. 82.

- and Haeger-Aronsen, B. (1963). Brit. med. ${ }^{7} .$,

Watson, C. J. (1960). New Engl. f. Med., 263, 1205.

\title{
Double-blind Experiments on the Effect of a Peanut Extract on the Bleeding Incidence in 92 Haemophiliacs*
}

\author{
M. VERSTRAETE, $†$ M.D. ; C. A. J. RUYS, $\ddagger$ M.D.
}

Brit. med. F., 1967, 4, 453-456

It is the fate of patients afflicted with a life-long disease to be subjected to therapeutic trials with new drugs or substances, of which the possible impact on the underlying diseases is not always apparent. A classical example is haemophilia ; a long list of drugs has stirred a fleeting hope in patients affected with this bleeding disorder when the new therapy coincides with one of their cyclic symptomless periods.

The fortuitous observation by a haemophilic patient that while consuming daily roasted peanuts the tenderness of an acute knee haemarthrosis seemed to subside more rapidly has

- Study organized with the kind co-operation of Belgian and Dutch groups interested in the treatment of haemophilia. Belgium Louvain (M. Verstraete, J. Vermylen, and $H$. Van Itterbeek) Netherlands: Ámsterdam (S. van Creveld, I. A. Mochtar, and J. Jonker), Leiden (E. A. Loeliger, A. Hensen, N. Fekkes, and J. J. Leeksma), Zevenaar (F. B. M. Verhey).

Associate Professor of Medicine, University of Louvain, Belgium.

Anvestigator ACF Amsterdam, Netherlands.

From the Laboratory of Blood Coagulation and Proteolysis, Department of Medicine, University of Louvain, Belgium. focused attention to a possible beneficial factor in peanuts for the treatment of haemophilia (Boudreaux et al., 1960). Largely because of untimely and uncontrolled rumours in the lay press, many haemophiliacs started experimenting on their own with any available source of peanuts-for example, commercial peanut butter, roasted and raw peanuts, or peanut flour.

The discovery of antifibrinolytic properties in peanuts, together with a possibly increased fibrinolytic potential in haemophiliacs (van Creveld et al., 1961), were thought to offer a reasonable basis for further investigation; also because in isolated studies a beneficial effect of peanuts or peanut extracts on the bleeding incidence of haemophilic patients continued to be reported (Brüster, 1961 ; Bisordi, 1964). Unfortunately these investigations were conducted in a limited number of patients and with a variety of peanut preparations (raw or roasted peanuts, peanut butter, peanut flour, or screw-pressed extracted peanut meal) or peanut extracts (crude peanut oil, hexane-extracted roasted peanuts, or $95 \%$ ethanol extract of peanut flour). 